\title{
Fast purification of trace vitellogenin from Chinese rare minnow using protein A-immobilized antibody
}

\author{
Maoyong Song • Xuefei Lv • Hailin Wang • Guibin Jiang
}

Received: 4 January 2008 /Revised: 30 January 2008 / Accepted: 11 February 2008 /Published online: 5 March 2008

(C) Springer-Verlag 2008

\begin{abstract}
Vitellogenin (Vtg) is a highly responsive biomarker for environmental exposure to various estrogenically active compounds. Here we present a simple, fast, mild, and stable immobilization of anti-Vtg antibody, and demonstrate its powerful applications for preconcentration and purification of fish Vtg proteins, allowing for the monitoring and screening of environmental exposure to estrogenically active compounds. In this immobilization method, rabbit antiserum containing a specific polyclonal antibody against Vtg was directly immobilized on an antibody-binding Staphylococcal protein A matrix $(\mathrm{SpA})$ without the need for prior purification. Under the unique elution conditions, the Vtg protein can be eluted out alone without any leaked specific antibody. The developed method was further used to purify Vtg from whole-body homogenate of Chinese rare minnow. Compared with previous purification methods, the isolated Vtg fraction by this method displays higher purity and well-preserved structure integrity. Moreover, our method is eight times faster. The simple one-step protein A-based specific antibody immobilization and its associated elution strategy may be extended to a number of antibodies for various application purposes, highlighting the paramount advantages over traditional immunoprecipitation and covalent immobilization of antibodies, and suggesting a wide range of promising applications in environmental monitoring and proteome analysis.
\end{abstract}

\footnotetext{
M. Song $\cdot$ X. Lv $\cdot$ H. Wang $\cdot$ G. Jiang $(\bowtie)$

State Key Laboratory of Environmental Chemistry and

Ecotoxicology, Research Center for Eco-Environmental Sciences,

Chinese Academy of Sciences,

P.O. Box 2871, Beijing 100085, China

e-mail: gbjiang@rcees.ac.cn
}

Keywords Vitellogenin (Vtg) - Affinity purification . Immobilized antibody

\section{Introduction}

Environmental estrogens are a group of chemical contaminants, which are widely present in the environment, and cause intense concern because of their potential adverse effects on development and reproduction of humans and wildlife [1-3]. Fish vitellogenin (Vtg) is generally considered as a highly responsive biomarker of environmental exposure to estrogenic compounds and for their screening [4-6]. It is a large, bulky phospholipoglycoprotein produced as the yolk protein precursor in fish liver. The synthesis of Vtg in the liver is under the estrogen-receptormediated regulation of $17 \alpha$-estradiol in both males and females $[4,7,8]$. It is normally undetectable in the plasma of males and immature females. Several studies demonstrated that even male fish captured from some polluted rivers and streams exhibited high levels of plasma Vtg, indicating the presence of environmental estrogens $[8,9]$.

Vitellogenin plays an important role as a valuable biomarker in the study of exposure to endocrine-disrupting compounds in fish. The purification of Vtg from fish is absolutely necessary in such studies [10-13]. A number of methods have been developed for the purification and enrichment of Vtg from various fish plasma, including gel filtration, ion-exchange chromatography, selective precipitation, and the combination of preparative ultracentrifugation and ion exchange chromatography [14], and these methods have been used to purify Vtg from the plasma of brown trout (Salmo trutta) [15], Arctic charr (Salvelinus alpinus) [16], eelpout (Zoarces viviparous) [17], English sole (Pleuronectes vetulus) [18], Carp (Cyprinus carpio) [19], and others fish [20]. 
Rare minnow (Gobiocypris rarus) is a member of the family Cyprinidis and native to China [21], and it has many attractive features such as small size $(2-8 \mathrm{~cm})$, wide temperature range $\left(0-35^{\circ} \mathrm{C}\right)$, short life cycle (approx. 4 months), ease of culture in the laboratory, and large egg production (average 266 eggs per hatch and continuous batch spawner) [22, 23]. Rare minnow is recommended as an aquatic toxic model fish in aquatic toxicity tests because it has been proved to be sensitive to heavy metals and xenoestrogens [24, 25]. However, existing methods for analysis, concentration, and purification of Vtg from this prospective model fish are very limited. On other hand, Vtg is very sensitive to proteolytic fragmentation and begins to degrade at $64 \mathrm{~min}$ during the purification process [26]. Tao et al. [27] used an anion-exchange chromatography to purify Vtg from rare minnow blood; however, the method is very time consuming (240 min) and some interferences of the sample matrix (such as lipid in the blood and homogenate) exist in the final product. The minnow's tiny size and limited blood combined with Vtg instability produce a great challenge to the analysis and purification of trace Vtg in rare minnow.

Here we present a simple one-step method for concentration and purification of trace $\mathrm{Vtg}$ in rare minnow. This procedure uses commercial protein A column as platform. The method takes advantage of the antibody-binding capacity of Staphylococcal protein A (SpA) to immobilize Vtg antibodies. SpA, a cell wall component of Staphylococcus aureus, has high affinity for immunoglobulin G (IgG) from various species, for instance humans, rabbits, and pigs [28, 29]. SpA displays high specific affinity for the Fc portion of various IgGs and therefore it does not cause any interruption of the binding capacity of the specific antibodies after binding [30]. Furthermore, in this method, we also developed unique elution conditions under which Vtg can be eluted without any accompanying specific antibody. The developed method is fast, and demonstrates high yield and high purity of final product.

\section{Experimental}

Reagents and instruments

$17 \alpha$-Estradiol was obtained from Sigma (St. Louis, MO, USA); a high-molecular-mass calibration kit for SDS electrophoresis was from Pharmacia (Amersham Pharmacia Biotech); electrophoresis gel and instrument were from Biorad (Hercules, CA, USA); other chemicals were from the Beijing Chemical Company. All the chemicals were of analytical reagent grade. Buffers and sample solutions were prepared with deionized water and filtered with a $0.22-\mu \mathrm{m}$ filter. Samples were filtered with a $0.45-\mu \mathrm{m}$ filter before experiments.

Polyclonal antiserum was obtained from rabbits raised against purified vitellogenin from hybridizer of carp and crucian using standard immunological methods described previously [31]. The antiserum was mixed with male plasma (no Vtg band in SDS-PAGE) at a ratio of 1:2 (v/v) to remove residual components common to both sexes. The mixture was incubated for $1 \mathrm{~h}$ at room temperature, then placed in an ice/water bath for $30 \mathrm{~min}$. After centrifuging at $10,000 \mathrm{~g}$ for $30 \mathrm{~min}$, the supernatant was collected and stored at $4{ }^{\circ} \mathrm{C}$.

HiTrap protein A affinity column (Pharmacia Biotech; Herts, UK) was used according to the manufacturer's instructions. The pump used in this work was Agilent 1100LC G1312A Binary pump (Agilent, Germany), which was controlled by an Agilent 1100LC workstation. A Shimadzu SPD-10A UV monitor (Shimadzu, Japan) and a WDL-95 chromatographic workstation (a kind gift from Professor Zou Hanfa at the Dalian Institute of Chemical Physics, Chinese Academy of Sciences) were used for online monitoring and data recording.

\section{Vtg induction}

Rare minnow was cultured in 10-L glass aquaria under semistatic conditions $\left(14 / 10 \mathrm{~h}\right.$ light/dark cycle; $\left.26{ }^{\circ} \mathrm{C}\right)$. Rare minnow was exposed to E2 at 20 ppb for 20 days. Only dimethyl sulfoxide (DMSO) was added in the control group. The exposure solution was renewed once a day.

After exposure, the fishes from each treatment group were collected and frozen at $-20{ }^{\circ} \mathrm{C}$. Once needed, fishes were thawed on ice and individually homogenized in icecold phosphate-buffered saline ( $\mathrm{pH} 7.5$, PBS) with 1:2 ratios of wet mass to buffer volume in a glass homogenizer. The homogenate was then centrifuged at $10,000 \mathrm{~g}$ for 15 min at $4{ }^{\circ} \mathrm{C}$, and the supernatant was withdrawn and immediately frozen at $-80^{\circ} \mathrm{C}$.

Immunoaffinity purification of $\mathrm{Vtg}$

This procedure uses commercial protein A column as platform and involves four sequential steps, and is described below in detail.

\section{Step 1: preparation of IgG-protein A matrix}

The column was balanced with buffer I (PBS, pH 7.0) at a flow rate of $1 \mathrm{~mL} \mathrm{~min}^{-1}$ for $10 \mathrm{~min}$. A total of $50 \mu \mathrm{L}$ of antiserum diluted in $2 \mathrm{~mL}$ buffer I was then injected onto the column and was washed at the same flow rate until all the unbound components were washed out. 


\section{Step 2: entrapment of Vtg from homogenate}

A $100-\mu \mathrm{L}$ aliquot of homogenate solution diluted in $2 \mathrm{~mL}$ buffer II (PBS, pH 8.0) was injected onto the column after the column had been balanced with this buffer. The column was washed at a flow rate of $1 \mathrm{~mL} \mathrm{~min}^{-1}$ with buffer II to remove all unbound components, until the UV baseline was reached. The unbound fraction was collected to test if all Vtg was entrapped by IgG-protein A matrix in SDS-PAGE.

\section{Step 3: purification of Vtg}

Before elution of Vtg, the column was prewashed with buffer III (PBS, $\mathrm{pH} 8.4$ ) to remove the nonspecific bound proteins. The column was then washed at a flow rate of

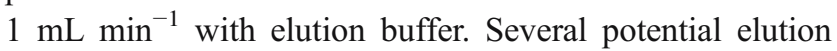
buffers were tested to determine the best conditions: $0.1 \mathrm{M}$ phosphate buffer ( $\mathrm{pH}$ 9.0-11.5), glycin buffer ( $\mathrm{pH} 3$ and 4), 0.1-0.01 M phosphate buffer (containing $5 \mathrm{M} \mathrm{LiCl,}$ $\mathrm{pH}$ 7.2), and 10\% 1,4-dioxane ( $\mathrm{pH}$ 7.0). The elution fractions were then collected in $5-\mathrm{mL}$ tubes containing $60 \mu \mathrm{L}$ of $1 \mathrm{M}$ Tris- $\mathrm{HCl}$ buffer ( $\mathrm{pH} 9.0, \mathrm{pH}$ adjustor) per $\mathrm{mL}$ of fraction to be collected.

\section{Step 4: elution of antibody}

After balancing with PBS buffer I, the column was washed with $0.1 \mathrm{M}$ critic acid buffer $(\mathrm{pH} \mathrm{3-6)}$ ) at a flow rate of $1 \mathrm{~mL} \min ^{-1}$. This step is optional.

After the purification procedure, the column was washed with five column volumes of $20 \%$ ethanol to prevent microbial growth and was stored at $4{ }^{\circ} \mathrm{C}$.

\section{Recovery analysis}

Because there is a lack of standard rare minnow Vtg, we use the purified Vtg to evaluate the recovery of the immunoaffinity purification (IAP) method. In detail, the Vtg fraction separated by IAP (about $5 \mathrm{~mL}$ ) was collected, then dialyzed in deionized water for $12 \mathrm{~h}$ and concentrated by freeze-drying. After diluting Vtg to PBS buffer I and measuring the Vtg solution concentrations, $200-\mu \mathrm{L}$, $400-\mu \mathrm{L}$, and $800-\mu \mathrm{L}$ aliquots of this solution were transferred to tubes containing $500 \mu \mathrm{L}$ control male loach plasma. The matrix was diluted to $3 \mathrm{~mL}$ with PBS buffer I. Under the optimized loading, rinsing, and elution conditions, the Vtg fraction was collected and the volume and concentration were measured. The recovery of the purification is estimated relative to the known loaded samples.

\section{Protein concentration measurement}

Protein concentration was measured using the Bradford method [32].

\section{SDS-PAGE and Western-blotting analysis}

SDS-PAGE electrophoresis was carried out according to the method of Laemmli [33], using discontinuous gel with a $4 \%$ stacking gel and a $7.5 \%$ resolving gel of acrylamide. For SDS-PAGE analysis, samples were diluted in sample buffer (125 mM Tris-HCl, $\mathrm{pH} 7.2$, containing 2\% SDS, $2 \%$ mercaptoethanol, 20\% glycerol, and $0.04 \%$ Bromophenol Blue) at a ratio $1: 1$ and heated to $95{ }^{\circ} \mathrm{C}$ for $10 \mathrm{~min}$ before electrophoresis. After electrophoresis, separated proteins were stained with Coomassie Brilliant Blue R250, and the bands were compared with high-molecular-mass electrophoresis standards.

The specificity of polyclonal antibodies against rare minnow Vtg was verified by Western blotting according to the method described by Shao [27]. Briefly, duplicate gels were produced according to the abovementioned SDSPAGE method. After electrophoresis, the separated proteins were transferred onto a nitrocellulose membrane by semidry blotting. Nonspecific binding of the membrane was blocked with 5\% dry nonfat milk in PBS ( $\mathrm{pH} 7.4)$ and kept overnight at $4{ }^{\circ} \mathrm{C}$. The membrane was then incubated with primary antibody $(2 \mathrm{~h})$ at 1:750 dilution in blocking buffer, followed by incubation with the second antibody (peroxidase-conjugated goat anti-rabbit $\mathrm{IgG}, 1: 1,500$ in $\mathrm{pH} 7.5$ Tris-HCl buffer) for $1.5 \mathrm{~h}$. Antigen-antibody complexes were visualized by the peroxidase reaction with 3',3'-diaminobenzidine and the reaction was terminated after $5 \mathrm{~min}$.

\section{Results and discussion}

\section{Cross-reactivity}

Currently there is no antibody specifically produced against rare minnow Vtg, but there are several polyclonal antibodies against Vtg from other fishes. It is possible to use these antibodies to recognize trace Vtg through their crossreactions. Our previous work demonstrates that one polyclonal antibody produced by rabbit raised against Vtg from a hybridized fish is able to specifically recognize Vtg proteins of carp and crucian. Here we further examined the ability of this polyclonal antibody to recognize Vtg of rare minnow. In SDS-PAGE analysis (Fig. 1A-C), a Vtg protein band appeared at MW $160 \mathrm{kD}$ in the homogenate of male 


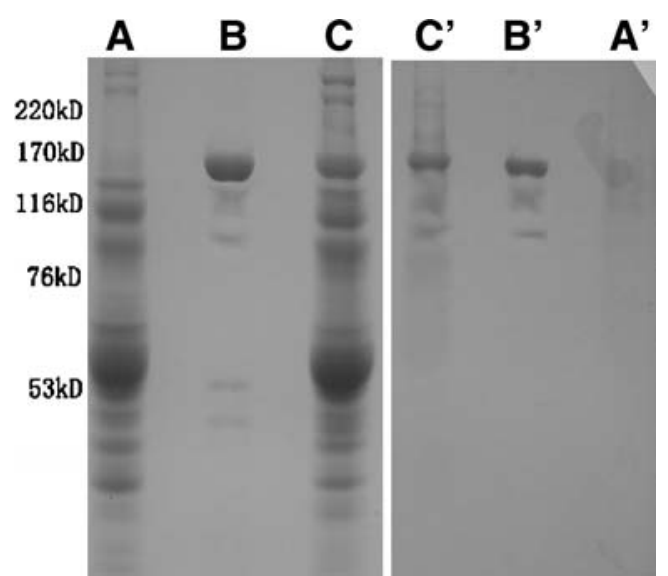

Fig. 1 Cross-reaction between the antigen (Vtg of Chinese rare minnow) and the antibody (antiserum of Vtg from hybrid fish) was analyzed by $13 \%$ SDS-PAGE gel $(A-C)$ and Western-blotting analysis $\left(A-C^{\prime}\right) . A, A^{\prime}$ plasma of male Chinese rare minnow; $B, B^{\prime}$ purified Chinese rare minnow Vtg; $C, C^{\prime}$ plasma of E2-induced male Chinese rare minnow

Chinese rare minnow stimulated by one estrogen E2 (lane C), but could not be observed in the control (lane A). Western-blotting analysis (Fig. $1 \mathrm{~A}^{\prime}-\mathrm{C}^{\prime}$ ) further validated the presence of $\mathrm{Vtg}$ protein in the homogenate of E2induced male Chinese rare minnow (lane $C^{\prime}$ ) and the absence in the control (lane $A^{\prime}$ ). Only the bands in SDSPAGE that can be specifically recognized by the Vtg polyclonal antibody with high affinity can appear in Western-blotting analysis. Indeed, most bands from SDSPAGE analysis disappeared in Western-blotting analysis, and bands associated with Vtg display strong signals in Western-blotting analysis. These results strongly suggest that the rabbit polyclonal antibody raised against Vtg from the hybrid fish also exhibits highly specific recognition of rare minnow Vtg protein. This high specificity and crossreactivity by the rabbit polyclonal antibody against rare minnow Vtg was further used in following concentration and purification of $\mathrm{Vtg}$ from the rare minnow.

\section{Entrapment of antibodies and vitellogenin}

In our previous work, the concentrations of $\mathrm{Vtg}$ in the blood of Chinese loach (Misgurnus anguillicaudatus) were arranged from 4 to $1,000 \mu \mathrm{g} \mathrm{mL}^{-1}$ before and after exposure to $17 \beta$ estradiol (E2), bisphenol A (BPA), and their mixtures [34]. Considering the volume of blood collected from Rare minnow (one fish) was only $5-10 \mu \mathrm{L}$, whole homogenized fish (Vtg is present in liver) was used instead of blood.

To purify Vtg protein, the rabbit polyclonal antibody against Vtg was first immobilized on protein A matrix through noncovalent binding. Rabbit antiserum containing the Vtg polyclonal antibody was directly injected onto the protein A column, and the impurities were rinsed out using buffer I. No antibody was detected in the rinsing solution of buffer I by native-PAGE analysis (Fig. 2, lane A), and antibody was detected in the rising solution of buffer III (Fig. 2, lane C), suggesting stable antibody-protein A complexes were formed on the column owning to the high affinity between protein $\mathrm{A}$ and the polyclonal antibody. In this developed method, no cross-linking chemicals, such as dimethyl pimelimidate dihydrochloride, were used because immobilization of antibodies with such agents can greatly affect the antigen-binding affinity of antibody due to incorrect orientations and denaturation [35].

We further examined the binding capacity and activity of the entrapped anti-Vtg antibody by protein A. In an experiment a constant amount of the rabbit polyclonal antibody $(50 \mu \mathrm{L}$ rabbit antiserum) was immobilized on protein A column, then undiluted Vtg-containing homogenate with volumes of $50,100,250$, and $500 \mu \mathrm{L}$ were loaded separately. The results from SDS-PAGE analysis (data not shown) indicated that all the Vtg in the homogenate was trapped by the protein $\mathrm{A}-\mathrm{IgG}$ complex after injection on the column, demonstrating a large binding capacity and a well-preserved activity of the rabbit anti- $\mathrm{Vtg}$ polyclonal antibody trapped on the protein A column.

The entrapped rabbit polyclonal antibody also exhibited fast binding kinetics. In our experiments, $500 \mu \mathrm{L}$ homogenates were passed through the column-immobilized anti-

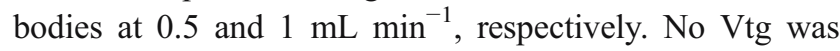
detected in the rinse-out fractions at either flow rate (data not shown), indicating capture of all the Vtg protein in the homogenates and no breakthrough of the target protein, further suggesting that the binding of Vtg of rare minnow to the protein A-immobilized rabbit polyclonal antibody is fast and stable. The fast binding kinetics may be due to the high specificity of protein A for the Fc fragment of $\mathrm{IgG}$, allowing a complete exposure of the antigen binding arms of the IgG in the solution.

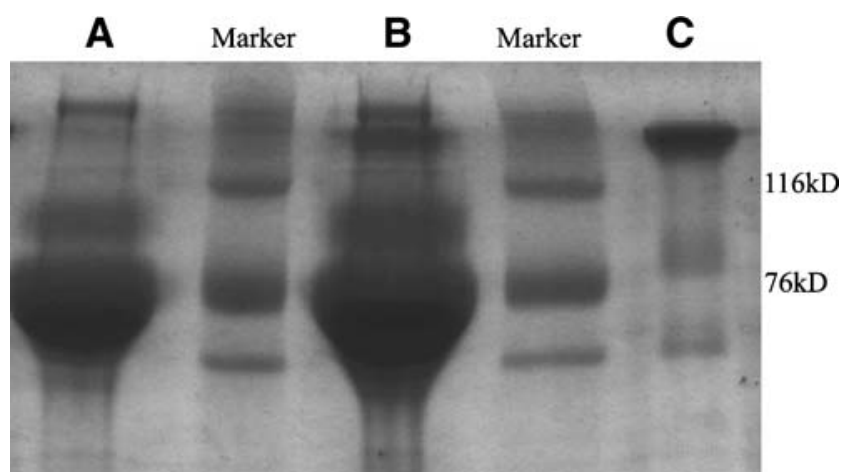

Fig. 2 Native-PAGE analyses of antibodies. $A$ fraction of antiserum eluted from protein A column by buffer I (PBS, pH 7.0), $B$ original antiserum, $C$ antibodies eluted from protein A column by citric acid buffer (pH 3.0). The molecular weight of antibody was about $150 \mathrm{kD}$ in native-PAGE and $53 \mathrm{kD}$ in SDS-PAGE (Fig. 5, lane 5, heavy chains of antibodies in SDS-PAGE) 


\section{Elution of Vtg from the protein A column}

The elution of bound Vtg of rare minnow on protein Aimmobilized rabbit polyclonal antibody column was optimized to elute out the target protein without coelution of the rabbit polyclonal antibody. Several elution buffers mentioned above were investigated. Previously studies have revealed that the antibodies could be eluted from a protein A column with citric acid. In the first set of experiments, only $0.1 \mathrm{M}$ phosphate buffer ( $\mathrm{pH} 10.6)$ eluted Vtg efficiently (Fig. 3, lane a). For other three elution buffers, glycin buffer ( $\mathrm{pH} 3$ and 4), $0.01 \mathrm{M}$ phosphate

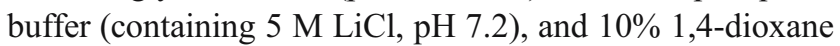
(pH 7.0), antibodies were eluted out from the column together with Vtg (Fig. 3b and c; Fig. 4, lane 2-4). At the end of all elution steps, buffer III was used to wash out rudimental antibodies and some nonspecific binding proteins from the column.

In another set of experiments, we further tested the effect of eluting buffer $\mathrm{pH}(0.1 \mathrm{M}$ phosphate buffer) on elution of Vtg (Fig. 5). The elution procedure relied on breaking the noncovalent bonds between the column and nonspecific binding proteins but maintaining the bonds between the antibodies and protein A. The results indicated Vtg could not elute from the matrix when the $\mathrm{pH}$ of buffer was lower than 11, and antibodies were washed out together with Vtg with the buffer of $\mathrm{pH}$ 11.5. We therefore chose the phosphate buffer with $\mathrm{pH} 10.6$ as elution buffer. Only Vtg could be effectively eluted under these conditions; however, both SDS-PAGE and Western-blotting analysis demonstrated that the purified Vtg has high purity (Fig. 1B and B'). The Western-blotting analysis also suggests the structure of $\mathrm{Vtg}$ is well preserved after this fast purification and no significant degradation fragments are observed. The purified Vtg could be used as standards in ELISA or used to produce polyclonal/monoclonal antibodies.

\section{Recovery}

The estimated recovery of the Vtg purification is shown in Table 1. All test samples gave high recoveries $(>90 \%)$, suggesting that most of the loaded Vtg was efficiently entrapped by protein A-immobilized anti-Vtg polyclonal antibody and also effectively eluted by and from the column.

This work demonstrates the unique capacity of rabbit anti-Vtg polyclonal antibody immobilized on protein A matrix. By use of this immobilized antibody, the purification of rare minnow Vtg can be achieved within $35 \mathrm{~min}$ from sample loading to the end of its elution, which is eight times faster than that by using an ion-exchange method (300 $\mathrm{min}$ ) [27]. The more rapid purification process also greatly reduced the degradation of $\mathrm{Vtg}$ and afforded a final
Fig. 3 Chromatogram of Vtg purification using the protein $\mathrm{A}$ column. All the equilibration, injections, and elutions were at a

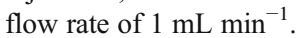

In- $I$ injection of antiserum, $I n-I I$ injection of homogenate, El-I elution with buffer III (PBS, $\mathrm{pH}$ 8.4), El-III elution with $0.1 \mathrm{M}$ citric acid buffer ( $\mathrm{pH} 3.0$ ). El-II elution with $0.1 \mathrm{M}$ phosphate buffer ( $\mathrm{pH}$ 10.6) (a), elution with $0.01 \mathrm{M}$ phosphate buffer (containing $5 \mathrm{M} \mathrm{LiCl}$, $\mathrm{pH}$ 7.2) (b); elution with $10 \%$ 1,4-dioxane solution (pH 7.0) (c)
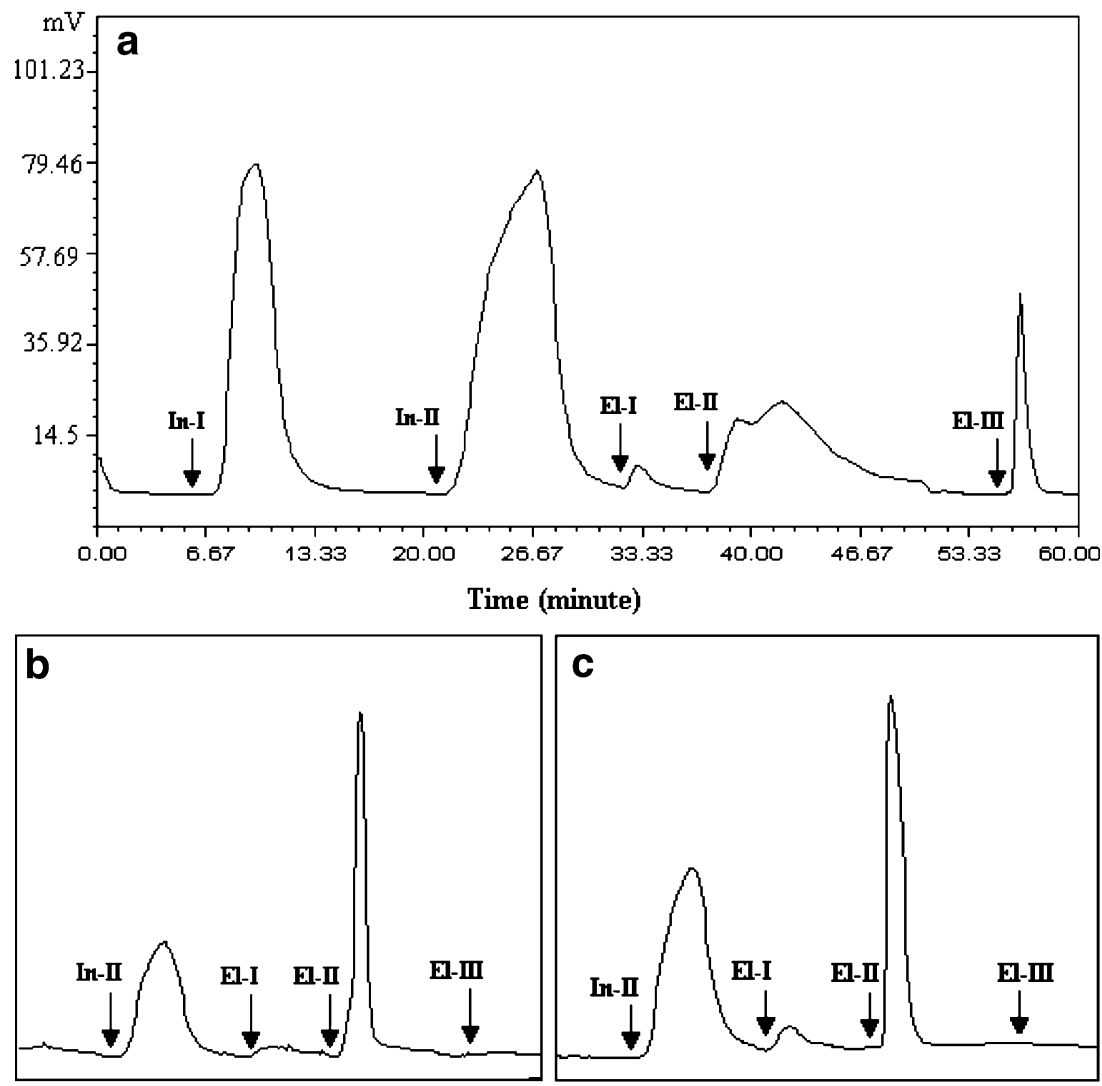

C

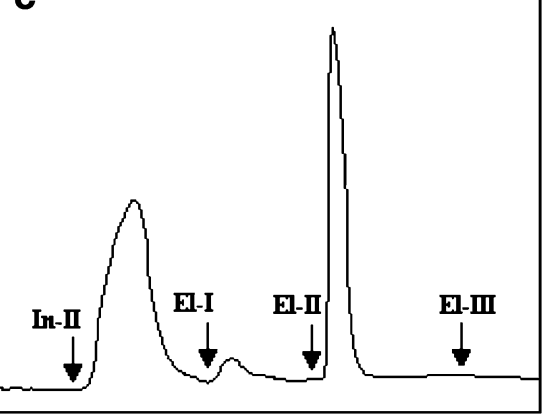




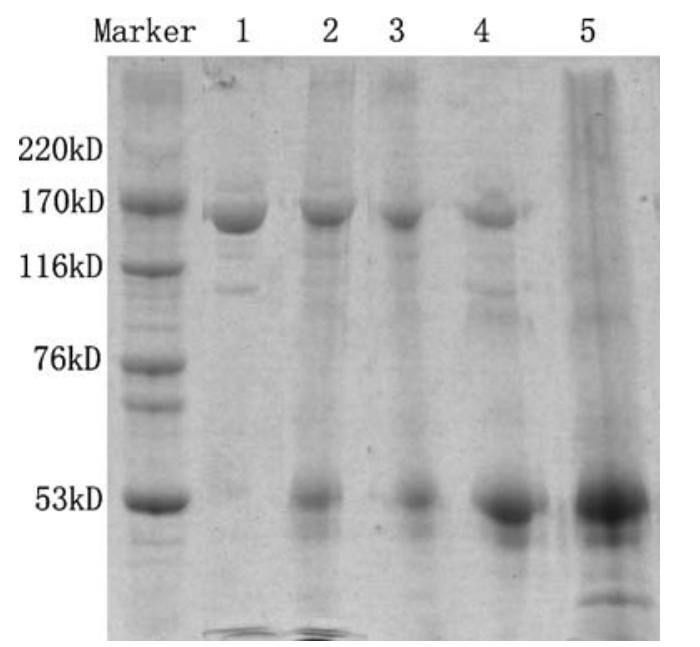

Fig. 4 SDS-PAGE analysis of purified Vtg from homogenate of rare minnow. Lane $1 \mathrm{Vtg}$ eluted with $0.1 \mathrm{M}$ phosphate buffer ( $\mathrm{pH} 10.6$ ), lane $2 \mathrm{Vtg}$ eluted with $0.1 \mathrm{M}$ phosphate buffer ( $\mathrm{pH} 11.5$ ), lane $3 \mathrm{Vtg}$ eluted with $0.01 \mathrm{M}$ phosphate buffer (containing $5 \mathrm{M} \mathrm{LiCl}, \mathrm{pH} 7.2$ ), lane 4 with $10 \%$ 1,4-dioxane solution $(\mathrm{pH} 7.0)$, lane 5 Abs eluted from protein A column by citric acid buffer ( $\mathrm{pH}$ 3.0)

product with high purity. The purification can be readily scaled up by loading appropriate amounts of antibody or antiserum. For example, $1 \mathrm{~mL}$ commercial HiTrapprotein A affinity column can mostly immobilize $2 \mathrm{mg}$ IgG. Moreover, efficient entrapment of low abundance targets $(\mathrm{Vtg})$ is expected, resulting in concentrated preparation. The immobilized antibody can be recovered and reused.

The immobilized anti-Vtg polyclonal antibody may also be useful to accurately measure Vtg for monitoring environmental exposure to estrogenic compounds by combining this technique with sensitive analytical methods including capillary electrophoresis, high-performance liquid chromatography, mass spectrometry, and so on.

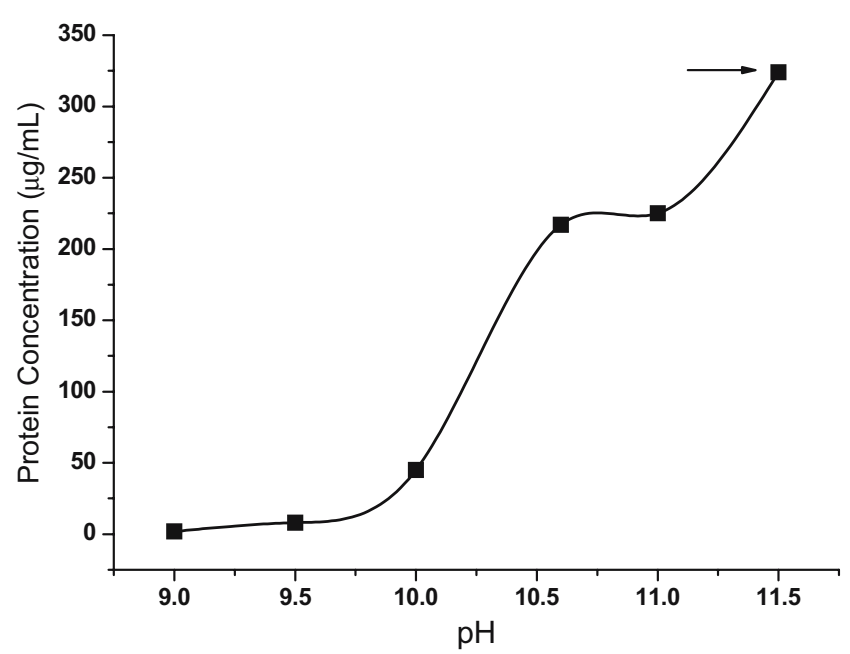

Fig. 5 Effect of elution buffer $\mathrm{pH}$ on Vtg purification from protein A column. Arrow antibodies were eluted from the column together with Vtg
Table 1 Vtg recovery by immunoaffinity purification (IAP) method

\begin{tabular}{lllll}
\hline Test & $\begin{array}{l}\text { Vtg added } \\
(\mathrm{mg})\end{array}$ & $\begin{array}{l}\text { Vtg collected } \\
(\mathrm{mg})\end{array}$ & $\begin{array}{l}\text { Recovery } \\
(\%)\end{array}$ & $\begin{array}{l}\text { RSD } \\
(\%)\end{array}$ \\
\hline 1 & 0 & $<0.01$ & 0 & 0 \\
2 & 0.258 & 0.243 & 93.0 & 8.4 \\
3 & 0.516 & 0.481 & 93.2 & 9.7 \\
4 & 1.032 & 1.007 & 97.6 & 7.2 \\
\hline
\end{tabular}

$N=3$

Various methods have been used for the isolation and purification of Vtg with the goal of increasing the purity of $\mathrm{Vtg}$ and preventing or slowing its breakdown. In this work, we have demonstrated a simple, rapid, and mild antibody immobilization technique. This immobilization technique has a number of advantages over traditional covalent immobilization: (a) the immobilization takes less than $10 \mathrm{~min}$ and is therefore much faster than traditional covalent immobilization methods which typically required hours to days; (b) it is also mild, and can be carried out under physiological conditions (phosphate buffer, $\mathrm{pH}$ 7.4); therefore the antibody shows well-preserved binding capacity and fast binding kinetics after immobilization; (c) no purification of antibody is required prior to immobilization. As demonstrated in this work, complex rabbit antiserum can be directly loaded for antibody immobilization; in contrast, the traditional covalent immobilization requires antibody of high purity to eliminate potential nonspecific adsorption. As demonstrated in the purification of rare minnow Vtg, the antigen can be eluted alone without any coelution of immobilized antibody, demonstrating an apparent advantage over traditional precipitation, in which antigen and antibody are precipitated together and further steps are required to remove the large amount of antibody. This also suggests powerful and prospective applications of this simple immobilization technique. It may be further extended to the immobilization of some antibodies on other ligands, e.g., protein $\mathrm{G}$ and protein $\mathrm{L}$.

\section{Conclusion}

In conclusion, we demonstrate a simple, rapid, and fast technique for antibody immobilization. Based on this technique, we developed a simple one-step and fast procedure for trace Vtg purification for complex fish homogenates.

Acknowledgements This work was jointly supported by State High Tech Development Plan (2006AA06Z424) and National Basic Research Program of China (2003CB415001 and 20707034). 


\section{References}

1. Colborn T, vom Saal F, Soto AM (1993) Environ Health Presp 101:378-384

2. Colborn T, Dumanoski D, Myers JP (1996) Our stolen future. Dutton, New York

3. Sohoni P, Tyler CR, Hurd K, Caunter J, Hetheridge M, Williams T, Woods C, Evans M, Toy R, Gargas M, Sumpter JP (2001) Environ Sci Technol 35:2917-2925

4. Heppell SA, Denslow ND, Folmar LC, Sullivan CV (1995) Environ Health Presp 103:9-15

5. Tyler CR, van Aerle R, Hutchinson TH, Maddix S, Trip H (1999) Environ Toxicol Chem 18:337-347

6. Jones PD, De Coen WM, Tremblay L, Giesy JP (2000) Water Sci Technol 42:1-14

7. Mommsen TP, Walsh PJ (1988) In: Hoar WS, Randall VJ (eds) Fish physiology, vol XIA. Academic, New York, pp 347-406

8. Folmar LC, Denslow ND, Rao V, Chow M, Crain DA, Enblom J, Marcino J, Guillette JLJ (1996) Environ Health Presp 104:1096-1101

9. Harries JE, Sheahan DA, Jobling S, Matthiessen P, Neall P, Routledge EJ, Rycroft R, Sumpter JP, Tylor T (1996) Environ Toxicol Chem 15:1993-2002

10. Tsutsui N, Ohira T, Kawazoe I, Takahashi A, Wilder MN (2007) Mar Biotechnol 9:360-369

11. Ferraz N, Carnevia D, Nande G, Rossotti M, Miguez MN, Last JA, Gonzalez-Sapienza G (2007) Anal Bioanal Chem 389:2195-202

12. Amano H, Fujita T, Hiramatsu N, Shimizu M, Sawaguchi S, Matsubara T, Kagawa H, Nagae M, Sullivan CV, Hara A (2007) J Exp Zool Part A Ecol Genet Physiol 307:324-341

13. Chen PJ, Rosenfeldt EJ, Kullman SW, Hinton DE, Linden KG (2007) Sci Total Environ 376:18-26

14. Komastsu K, Matsumoto W, Hayashi S (1996) Comp Biochem Physiol 113:561-571
15. Sherry J, Gamble A, Fielden M, Hodson P, Burnison B, Solomon K (1999) Sci Total Environ 225:13-31

16. Johnsen HK, Tveiten H, Willassen NP, Arnesen AM (1999) Comp Biochem Physiol B 124:355-362

17. Korsgaard B, Pedersen KL (1998) Comp Biochem Physiol C 120:159-166

18. Lomax DP, Roubal WT, Moore JD, Johnson LL (1998) Comp Biochem Physiol B 121:425-436

19. Magalhães I, Ledrich ML, Pihan JC, Falla J (2004) J Chromatogr B 799:87-93

20. Brion F, Rogerieux F, Noury P, Migeon B, Flammarion P, Thybaud E, Porcher JM (2002) J Chromatogr B 737:3-12

21. Re MR, Fu TY (1983) Acta Zootaxonomica Sin 8:434-437

22. Wang JW (1993) Acta Hydrobiol Sin 23:161-166

23. Zhong XP, Xu Y, Liang Y, Liao T, Wang JW (2004) Comp Biochem Physiol C 137:291-298

24. Zhou YX, Cheng SP, Hu W, Song MJ (1995) Zool Res 16:59-63

25. Lu L, Shen YW (2002) Res Environ Sci 15:57-59

26. Inaba K, Buerano CC, Natividad FF, Morisawa M (1997) Comp Biochem Physiol C 118:85-90

27. Liao T, Jin SW, Yang FX, Hui Y, Xu Y (2006) Sci Total Environ 364:284

28. Moks T, Abrahmsen L, Nilsson B, Hellman U, Sjoquist J, Uhlen M (1986) Eur J Biochem 156:637-643

29. Richman DD, Cleveland PH, Oxman MN, Johnson KM (1982) J Immunol 128:2300-2305

30. Langone JJ (1982) Adv Immunol 32:157-252

31. Shao J, Shi GQ, Song MY, Jiang GB (2005) Environ Int 31:763-770

32. Bradford MM (1976) Analy Biochem 72:248-254

33. Laemmli UK (1970) Nature 227:680-685

34. Lv X, Zhou Q, Song M, Jiang G, Shao J (2007) Environ Toxicol Pharmacol 24:155-159

35. Kanno S, Yanagida Y, Haruyama T, Kobatake E, Aizawa M (2000) J Biotechnol 76:207-214 